Annals of Warsaw University of Life Sciences - SGGW

Land Reclamation No 45 (2), 2013: 235-242

(Ann. Warsaw Univ. of Life Sci. - SGGW, Land Reclam. 45 (2), 2013)

\title{
Influence of meteorological conditions on the yield of winter oilseed rape in Lower Silesia
}

\author{
HALINA DZIEŻYC ${ }^{1}$, KAZIMIERZ CHMURA ${ }^{2}$, MACIEJ PIOTROWSKI ${ }^{2}$ \\ ${ }^{1}$ Department of Spatial Economy, Wrocław University of Environmental and Life Sciences \\ ${ }^{2}$ Institute of Landscape Architecture, Wrocław University of Environmental and Life Sciences
}

\begin{abstract}
Influence of meteorological conditions on the yield of winter oilseed rape in Lower Silesia. This work uses the results of Post-registration Cultivar and Agricultural Experimentation conducted in 1999-2011 in Lower Silesia, on soils of very good and good wheat complex. The rape vegetation season was divided into five periods that approximately corresponded to the phenological phases of the plant, namely: September-November (from sowing to stemming the growing season in the autumn), December-March (stunted vegetation - renewal of vegetation), April (renewal of vegetation - the beginning of flowering), May (flowering), June (end of flowering - technical maturity). In the constructed regression model the following factors were included: the average air temperature and total precipitation in the periods, the content of phosphorus, potassium and $\mathrm{pH}$ of soil and fertilization with nitrogen, phosphorus and potassium. Comparing the impact of meteorological conditions in different growing periods of winter rape, it was found that the weakest impact on the yield had temperature and precipitation from September to November. During this period, the optimum for yield are the following conditions: average temperature $10.4^{\circ} \mathrm{C}$ and precipitation total $145 \mathrm{~mm}$. The winter period (December-March) has the strongest impact on the yield of rape. The yield is conspicuously higher with lower average air temperatures. Optimal for yield is precipitation of $171 \mathrm{~mm}$ (highest tested) and a relatively low average air temperature $\left(-0.9^{\circ} \mathrm{C}\right)$. In April, the decisive factor is rainfall. Its lower values $(12 \mathrm{~mm})$ favour higher yield. The optimum weather in this period is $12 \mathrm{~mm}$ precipitation and average temperature of $9.1^{\circ} \mathrm{C}$. Rape yield increases with increasing average air temperature in May and is highest when its value is $15^{\circ} \mathrm{C}$ and rainfall in this month is above average $(73 \mathrm{~mm})$. The
\end{abstract}

weather in June has less impact on rape crop than in the three previous periods. The optimal layout is: $27 \mathrm{~mm}$ precipitation and temperature $16^{\circ} \mathrm{C}$, these values being the smallest tested.

Key words: winter oilseed rape, precipitation, temperature, Lower Silesia

\section{INTRODUCTION}

Winter rape belongs to plants which are highly responsive to changing weather conditions (Kotecki et al. 2004, Wielebski 2009), but studies on the weather impact on yielding of this species are not numerous. They come mainly from the last century, while, in comparison with other crop species, in the case of rape a large breeding progress has been recorded. For instance, in the year 2012, 15 new varieties were registered (Kotowicz 2012). Participation of this plant in the structure of crops in Lower Silesia is one of the highest in the country, and in recent years it ranged from 10 to $14 \%$. During the decade 2000-2010, rape crop in the area doubled (Kotowicz 2012). It seems, therefore, appropriate to determine, on the basis of data from Lower Silesia, which temperature and precipitation conditions affect yielding of this species as represented by modern varieties. 


\section{MATERIAL AND METHODS}

This work uses the results of Post-registration Cultivar and Agricultural Experimentation (formerly Post-registration Cultivar Experimentation) carried out in the years 1999-2011 in Lower Silesia in Głubczyce, Tomaszów Bolesławiecki, Tarnów, Krościna Mała, Pawłowice, Zybiszów, Naroczyce. Rape was grown mostly on soils of very good and good wheat complex; hence, to eliminate the quality of soil factor, data were considered from these two complexes only. The growing time of rape was divided into five periods corresponding approximately to phenologic stages of this plant, namely: a) September-November (from sowing to stemming the vegetation in the autumn), b) December-March (stunted vegetation - renewal of vegetation), c) April (renewal of vegetation - the beginning of flowering), d) May (flowering), e) June (end of flowering - technical maturity).

Using the regression method, rape seed yield variation was examined as influenced by the amount of precipitation and the average temperature of the air in the above periods. In addition, the created model includes: content of $\mathrm{P}_{2} \mathrm{O}_{5}$ and $\mathrm{K}_{2} \mathrm{O}$ in the soil, soil $\mathrm{pH}$ in $\mathrm{KCl}$, fertilization with nitrogen, phosphorus and potassium. The model has the following form:

$$
\begin{aligned}
& y=b_{0}+\sum_{i=1}^{5}\left(b_{i} x_{i}+b_{i i} x_{i}^{2}+b_{i+5} x_{i+5}+b_{i+5, i+5} x_{i+5}^{2}\right)+ \\
& +\sum_{i=11}^{16}\left(b_{i} x_{i}\right)
\end{aligned}
$$

where:

$y$ - grain yield [dt/ha], $x_{1}$ - rainfall [mm] in September-November,

$x_{2}-$ rainfall $[\mathrm{mm}]$ in December-March, $x_{3}-$ rainfall $[\mathrm{mm}]$ in April, $x_{4}-$ rainfall $[\mathrm{mm}]$ in May, $x_{5}-$ rainfall $[\mathrm{mm}]$ in June, $x_{6}$ - mean temperature $\left[{ }^{\circ} \mathrm{C}\right]$ in September-November,

$x_{7}$ - mean temperature $\left[{ }^{\circ} \mathrm{C}\right]$ in December-March, $x_{8}$ - mean temperature $\left[{ }^{\circ} \mathrm{C}\right]$ in April, $x_{9}$ - mean temperature $\left[{ }^{\circ} \mathrm{C}\right]$ in May, $x_{10}-$ mean temperature $\left[{ }^{\circ} \mathrm{C}\right]$ in June, $x_{11}-$ content of $\mathrm{P}_{2} \mathrm{O}_{5}[\mathrm{mg} / 100 \mathrm{~g}$ soil], $x_{12}-$ content of $\mathrm{K}_{2} \mathrm{O}$ [mg/100 g soil], $x_{13}-$ soil $\mathrm{pH}$, $x_{14}-$ nitrogen fertilization $[\mathrm{kg} / \mathrm{ha}]$, $x_{15}$ - phosphorous fertilization [ $\mathrm{kg} / \mathrm{ha}$ ], $x_{16}$ - potassium fertilization [ $\mathrm{kg} / \mathrm{ha}$ ].

Calculations were conducted for 656 cases, and after eliminating the outliers (absolute value of standardized residuals >2) -626 .

Based on the regression equation, for each of the periods considered $(i=1, \ldots$ $5)$, the functions were plotted:

$$
\begin{aligned}
& f_{i}\left(x_{i}, x_{i+5}\right)=b_{i} x_{i}+b_{i i} x_{i}^{2}+b_{i+5} x_{i+5}+ \\
& +b_{i+5}, i+5 x_{i+5}{ }^{2}+c_{i}
\end{aligned}
$$

where: $c_{i}$ - constant selected so that the minimum value of the function $f_{i}\left(x_{i}, x_{i+5}\right)$ in the studied range of variables, i.e. average of $x_{i} \pm$ standard deviation and average of $x_{i+5} \pm$ standard deviation, was 0 . These functions illustrate the variability in yield under the influence of meteorological factors during a particular rape growing period. Also a graphic representation is given of the relationship between yield and the other factors included in the model. 


\section{RESULTS AND DISCUSSION}

Meteorological conditions during the period from sowing to autumn - stunted vegetation (September-November) have a relatively small impact on the yield of rape. Optimum temperature and precipitation during this time, in the ranges 7.6$-10.4{ }^{\circ} \mathrm{C}$ and $77-145 \mathrm{~mm}$, are $10.4{ }^{\circ} \mathrm{C}$ and $145 \mathrm{~mm}$, respectively (Table 1, Fig. 1a). Especially for precipitation, differences in yield for its various quantities are small. Nowicka (1993), on the basis of models, calculated for south-western and entire Poland, of winter rape yielding on wheat soils, obtained similar values of the optimal temperature during that period, i.e. $9.5^{\circ} \mathrm{C}$ and $10.6^{\circ} \mathrm{C}$, respectively. Literature data confirm the lack of impact on the yield of the water factor during autumn. Dembiński and Muśnicki (1992) state that from emergence to stunted vegetation the winter rape is not sensitive to shortages of rainfall owing to the deep-reaching taproot as well as to the profuse autumn dews. According to Berbeć and Malicki (1989), who deal with water needs of rape from irrigation, in the Polish conditions there is no need for interfering in water management by this plant before winter.

The next period, i.e. December-March, affect the yield of rape in the strongest way (Fig. 1b). The difference between the optimum conditions and the least favorable is $27.3 \mathrm{dt} / \mathrm{ha}$. In the examined ranges of temperature and precipitation, $-1.4-2.6^{\circ} \mathrm{C}$ and $111-175 \mathrm{~mm}$, the most beneficial are: $-0.9^{\circ} \mathrm{C}$ and $171 \mathrm{~mm}$. Yield significantly decreases with increasing temperatures, a minimum corresponds to the highest temperature tested of $2.6^{\circ} \mathrm{C}$ and lowest precipitation of $111 \mathrm{~mm}$. High temperatures in winter cause acceleration of flowering (Bartoszek 2013), during which severe frosts may occur, causing weak binding of siliques (Kotowicz 2007). According to Nowicka (1993), the optimum temperature during inhibition of vegetation is $-0.5^{\circ} \mathrm{C}$ for the model for south-west Poland and $-1.9^{\circ} \mathrm{C}$ for the model for entire Poland.

In April, that is during the period between the spring start of vegetation and the time of flowering, winter rape grown on wheat soils is sensitive to excess water

TABLE 1. Optimal and least favorable conditions for yielding of winter oilseed rape in particular periods

\begin{tabular}{|l|c|c|c|c|c|}
\hline Period & $\begin{array}{c}\text { Range of } \\
\text { temperature } \\
{\left[{ }^{\circ} \mathrm{C}\right]}\end{array}$ & $\begin{array}{c}\text { Range of } \\
\text { precipitation } \\
{[\mathrm{mm}]}\end{array}$ & $\begin{array}{c}\text { Optimal } \\
\text { conditions } \\
\text { temperature } \\
{\left[{ }^{\circ} \mathrm{C}\right] / \text { precipi- }} \\
\text { tation }[\mathrm{mm}]\end{array}$ & $\begin{array}{c}\text { Least } \\
\text { favorable } \\
\text { conditions } \\
\text { temperature } \\
{\left[{ }^{\circ} \mathrm{C}\right] /} \\
\text { precipitation } \\
{[\mathrm{mm}]}\end{array}$ & $\begin{array}{c}\text { The dif- } \\
\text { ference in } \\
\text { yield }[\mathrm{dt} / \mathrm{ha}] \\
\text { between } \\
\text { optimal } \\
\text { and least } \\
\text { favorable } \\
\text { conditions }\end{array}$ \\
\hline September-November & $7.6-10.4$ & $77-147$ & $10.4 / 145$ & $7.6 / 110$ & 7.15 \\
\hline December-March & $-1.4-2.6$ & $111-171$ & $-0.9 / 171$ & $2.6 / 111$ & 27.3 \\
\hline April & $8.5-10.7$ & $12-56$ & $9.1 / 12$ & $10.7 / 47$ & 16.5 \\
\hline May & $12.8-15.0$ & $30-102$ & $15.0 / 73$ & $12.8 / 30$ & 13.2 \\
\hline June & $16.0-18.6$ & $27-107$ & $16.0 / 27$ & $18.6 / 107$ & 12.2 \\
\hline
\end{tabular}



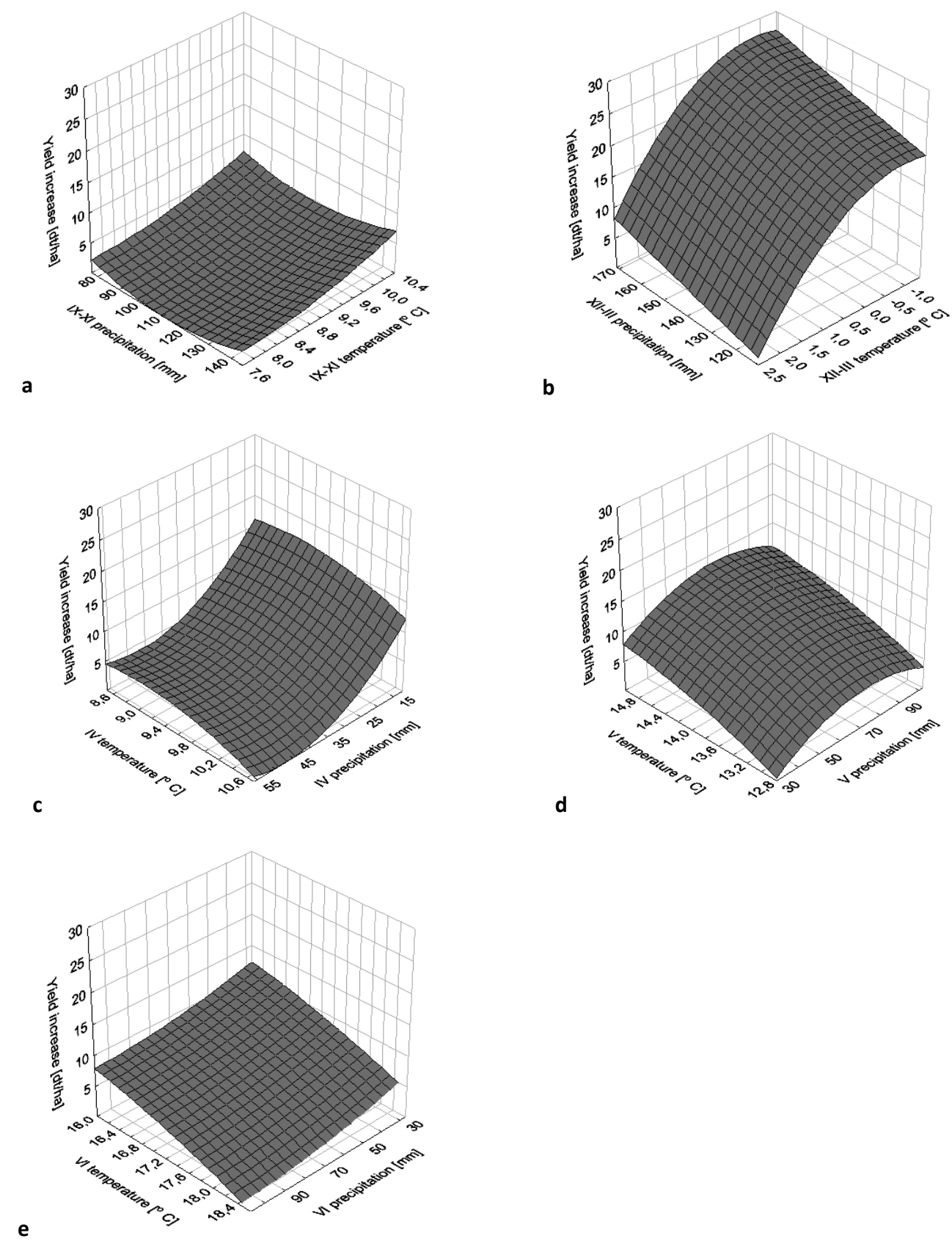

FIGURE 1. Increases of yield of winter oilseed rape under the influence of average temperature and precipitation during: $\mathrm{a}$ - September-November, $\mathrm{b}$ - December-March, $\mathrm{c}-$ April, $\mathrm{d}$ - May, e - June 
(Fig. 1c). In the tested intervals of temperature and precipitation, $8.5-10.7^{\circ} \mathrm{C}$ and $12-56 \mathrm{~mm}$, the least favorable conditions are $10.7^{\circ} \mathrm{C}$ and $47 \mathrm{~mm}$, and the optimum ones are $9.1^{\circ} \mathrm{C}$ and $12 \mathrm{~mm}$. The difference in the yields for these conditions is $16.5 \mathrm{dt} / \mathrm{ha}$. In this period the plant uses water supplies from the winter. Its excess causes rot of rape (Dembiński and Muśnicki 1992). According to Nowicka (1993), the best thermal conditions for rape during the period from vegetation start to beginning of flowering for south-western Poland is $9.7^{\circ} \mathrm{C}$. Described in the literature (Dzieżyc 1988, Nyc 2006) optimal precipitation in April for this plant is about $50 \mathrm{~mm}$, which hasn't been confirmed in our studies.

May is the month in which the water needs of rape are highest. Good yield is also boosted during this period by higher temperatures (Fig. 1d). Optimal yield obtains with $73 \mathrm{~mm}$ precipitation and daily mean temperature of $15^{\circ} \mathrm{C}$ (highest tested). The least favorable conditions is the lowest tested precipitation $(30 \mathrm{~mm})$ and lowest temperature $\left(12.8^{\circ} \mathrm{C}\right)$. The difference in yield between those conditions and optimum is $13.2 \mathrm{dt} / \mathrm{ha}$. However, the increase in precipitation above $73 \mathrm{~mm}$ results in a reduction of the yield in relation to the maximum. These results confirm previous studies of other authors. Nowicka (1993) took 16.3 and $17.5^{\circ} \mathrm{C}$ as the optimum for the region of Lower Silesia and Poland, respectively. The flowering phase is indicated in the literature as a critical period in rape water management. The direct cause of lowering the yields due to insufficient rainfall is drooping flowers or untying the seeds in silique (Dembiński and Muśnicki 1992). According to Wójtowicz (2005), a lack of rainfall during flowering reduces the silique per plant and consequently lowers the yield. Water needs of rape, by other authors, depend on the soil and cultivation region, amounting to about 65-80 mm (Dzieżyc 1988, Nyc 2006). A negative impact on rape yield of high rainfall in the flowering phase was concluded on the basis of a synthesis of research from 14 European countries by Peltonen-Sainio et al. (2010).

In June, both the thermal and rainfall requirements of rape are small (Fig. 1e). In the examined range of $16.0-18.6^{\circ} \mathrm{C}$ and $27-105 \mathrm{~mm}$ the most appropriate are the lowest tested temperature and precipitation, and the least beneficial - the highest values of these parameters. The difference in yield for these conditions is $12.2 \mathrm{dt} / \mathrm{ha}$. By Nowicka (1993), the best in the last phenological phase of the rape are high temperatures, $18.3^{\circ} \mathrm{C}$ for the south-west and $18.2^{\circ} \mathrm{C}$ for entire Poland. Significantly higher (about $70 \mathrm{~mm}$ ), by other authors (Dzieżyc 1988, Nyc 2006), is also the optimal precipitation during that period. In the literature, however, you can also find the idea that the yield of rape is largely favored not by precipitation but the humidity of the air (Dembiński and Muśnicki 1992), whose higher values are achieved at lower temperatures.

Analysis of the model confirmed, in addition, a positive impact of the content in soil of phosphorus and potassium as well as N, P and $\mathrm{K}$ fertilization (Fig. 2).

\section{CONCLUSIONS}

1. Optimal meteorological factors for the yield of rape during the period from September to November are 

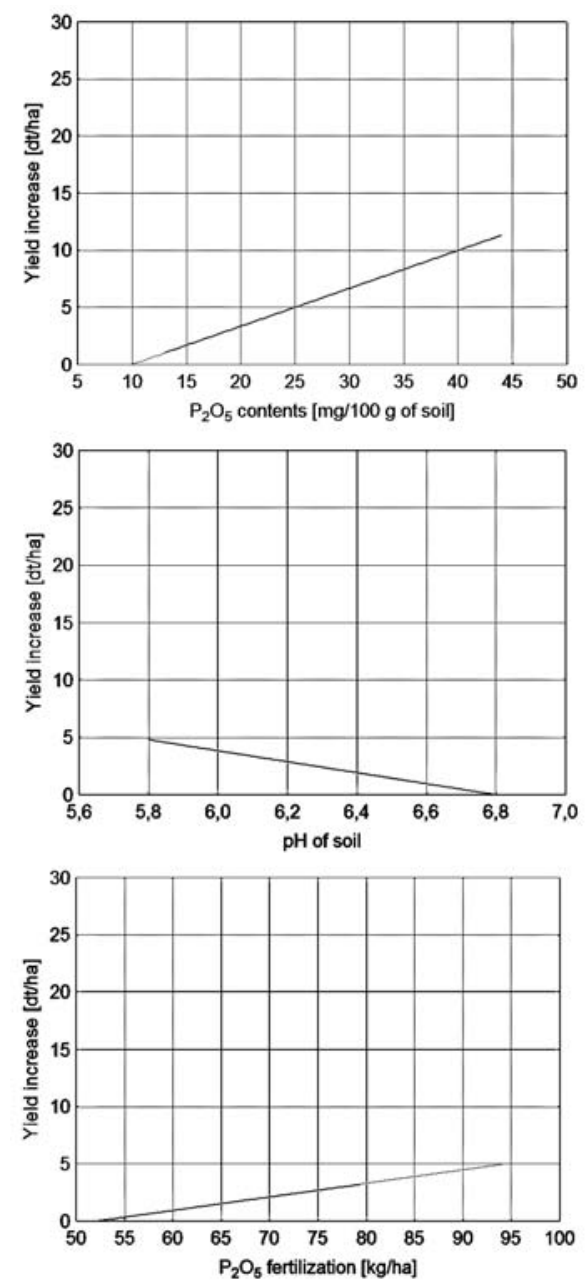
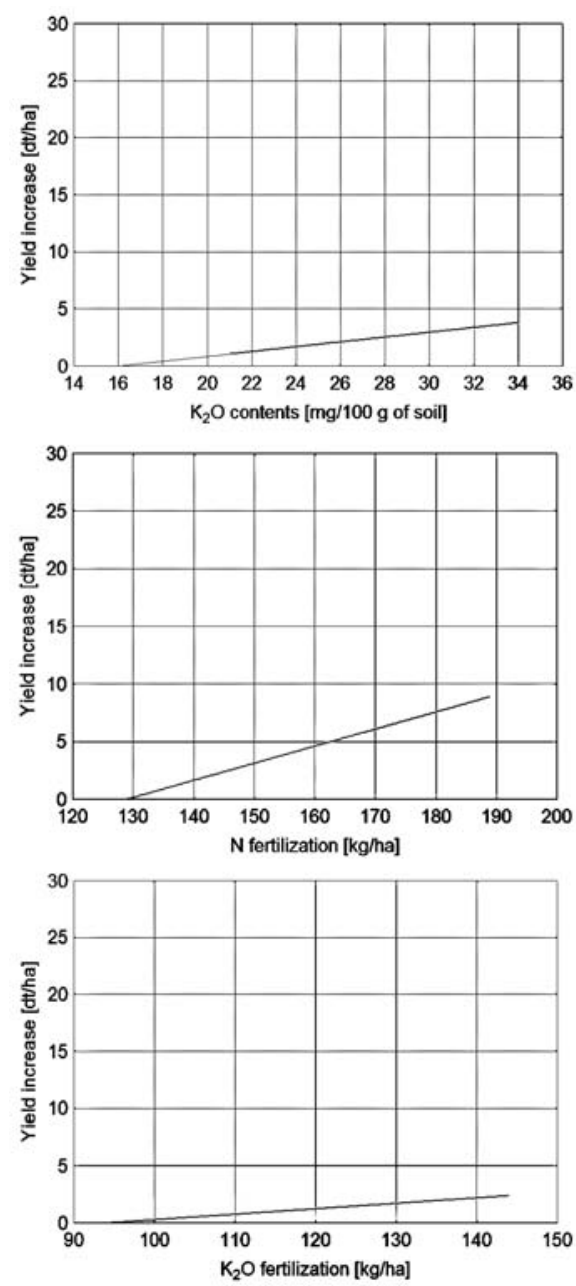

FIGURE 2. Effect of other factors included in the model on the yield of winter oilseed rape

the following: average temperature $10.4^{\circ} \mathrm{C}$ and precipitation $145 \mathrm{~mm}$, although weather conditions of this period have a relatively small impact on yield.

2. The strongest influence on yielding of rape has the winter period (December-March). Optimal for yield is the rainfall of $171 \mathrm{~mm}$ (highest tested) and low average air temperature $\left(-0.9^{\circ} \mathrm{C}\right)$. Due to importance of snow cover parameters in overwintering, the influence of this period requires additional further research.

3. In April, the decisive factor is rainfall. Optimal weather conditions in this period is rainfall of $12 \mathrm{~mm}$ and average temperature of $9.1^{\circ} \mathrm{C}$.

4. Rape yield increases with increasing average air temperature in May, and is highest when its value is $15^{\circ} \mathrm{C}$ and that of rainfall $73 \mathrm{~mm}$. 
5. The thermal and precipitation needs of rape in June are small, the optimum is rainfall of $27 \mathrm{~mm}$ and temperature of $16^{\circ} \mathrm{C}$.

\section{REFERENCES}

BARTOSZEK K. 2013: Wpływ warunków meteorologicznych na początek wybranych faz rozwojowych rzepaku ozimego wiosną i latem [Impact of weather conditions on the onset of selected stages of winter rape seed in spring and summer]. Acta Agrophysica 20 (2): 227-240 [Engl. Summ.].

BERBEĆ S., MALICKI L. 1989: Potrzeby wodne roślin przemysłowych. [Water needs of industrial plants]. In: J. Dzieżyc [Ed.]. Potrzeby wodne roślin uprawnych [Water needs of crop plants]. PWN, Warszawa: 119-136.

DEMBIŃSKI F., MUŚNICKI C. 1992: Rzepak ozimy i rzepik ozimy [Winter oilseed rape and turnip rape]. In: Z. Hryncewicz. [Ed.]. Uprawa roślin rolniczych [Crops growing]. PWRiL, Warszawa: 196-219.

DZIEŻYC J. 1988: Rolnictwo w warunkach nawadniania [Argiculture in irrigation conditions]. PWN, Warszawa: 5-415.

KOTECKI A., KOZAK M., MALARZ W. 2004: Wpływ zróżnicowanego poziomu agrotechniki na rozwój i plonowanie odmian rzepaku ozimego [The effect of different crop production systems on growth and yielding of winter rape cultivars]. Rośliny Oleiste [Oilseed Crops] Vol. XXV: 97-107.

KOTOWICZ L. 2007: Wyniki Porejestrowych Doświadczeń Odmianowych na Dolnym Śląsku. Rzepak ozimy. 2007 (2005-2007) [The results of After Registration Variety Researches on Lower Silesia. Winter oilseed rape 2007 (2005-2007)]. Dolnośląski Zespół PDOiR 1(9): $1-18$.

KOTOWICZ L. 2012: Rzepak ozimy. Porównanie plonowania odmian populacyj- nych i mieszańcowych w zależności od rodzaju gleb [Winter rape. Comparison of yielding cultivars and hybrids depending on the type of soil]. Dolnośląski Zespół PDOiR 2 (14): 1-29.

NOWICKA A. 1993: Temperatura [Temperature]. In: J. Dzieżyc [Ed.]. Czynniki plonotwórcze - plonowanie roślin [Yield-Forming Factors - Plant Yielding].Wydawnictwo Naukowe PWN, Warszawa: 99-148.

NYC K. 2006: Wprowadzanie systemów nawadniających [Entering irrigation systems]. In: S. Karczmarczyk, L. Nowak [Eds.]. Potrzeby wodne roślin uprawnych [Water needs of crop plants]. PWRiL, Poznań: 157-174.

PELTONEN-SAINIO P., JAUHIAINEN L., TRNKA M., OLESEN J.E., CALANCA P., ECKERSTEN H., EITZINGER J., GOBIN A., KERSEBAUM K.Ch., KOZYRA J., KUMAR S., MARTA A.D., MICALE F., SCHAAP B., SEGUIN B., SKJELVÅGA.O., ORLANDINI S. 2010: Coincidence of variation in yield and climate in Europe. Agriculture, Ecosystems and Environment 139 (4): 483-489.

WIELEBSKI F. 2009: Reakcja różnych typów hodowlanych odmian rzepaku ozimego na poziom stosowanej agrotechniki. I. Charakterystyka dojrzewających roślin rzepaku oraz jego plonowanie i układ elementów plonotwórczych [Response of different types of winter oilseed rape varieties to crop production systems. I. Characteristics of ripening plants of oilseed rape and components of seed yield]. Rośliny Oleiste Oilseed Crops]. Vol. XXX: 75-90.

WÓJTOWICZ M. 2005: Wpływ warunków środowiskowych na zmienność i współzależność pomiędzy plonem nasion rzepaku ozimego oraz komponentami jego struktury [Effect of environmental conditions on variability and interaction between yield and its components in winter oilseed rape]. Rośliny Oleiste [Oilseed Crops] Vol. XXVI: 99-110. 
Streszczenie: Wpływ warunków meteorologicznych na plonowanie rzepaku ozimego na Dolnym Ślqsku. W pracy wykorzystano wyniki Porejestrowego Doświadczalnictwa Odmianowego i Rolniczego (dawniej Porejestrowego Doświadczalnictwa Odmianowego) prowadzonego w latach 1999-2011 na Dolnym Śląsku na glebach kompleksów pszennego bardzo dobrego i pszennego dobrego. Czas wegetacji rzepaku podzielono na pięć okresów odpowiadających w przybliżeniu fazom fenologicznym tej rośliny, mianowicie: wrzesień-listopad (od siewu do zahamowania wegetacji jesienia), grudzień-marzec (zahamowanie wegetacji - wznowienie wegetacji), kwiecień (wznowienie wegetacji - początek kwitnienia), maj (kwitnienie), czerwiec (koniec kwitnienia - dojrzałość techniczna). W zbudowanym modelu regresji uwzględniono następujące czynniki: średnią temperaturę powietrza i sumę opadów w ww. okresach, zawartość fosforu, potasu i pH gleby oraz nawożenie azotem, fosforem i potasem. Uzyskaną funkcję badano w przedziale średnia \pm odchylenie standardowe dla każdego czynnika. Porównując oddziaływanie warunków meteorologicznych w poszczególnych okresach wegetacji rzepaku ozimego, stwierdzono, że najsłabszy wpływ na jego plon ma temperatura i opad od września do listopada. W okresie tym optymalnym dla plonu jest układ czynników: średnia temperatura $-10,4^{\circ} \mathrm{C}$ i suma opadów $-145 \mathrm{~mm}$. Okres zimowy (grudzień-marzec) ma zaś najsilniejszy wpływ na plonowanie rzepaku. Plon jest zdecydowanie większy przy niższych średnich wartościach temperatury powietrza. Optymalny dla plonu jest opad wynoszący $171 \mathrm{~mm}$ (największy badany) i stosunkowo niska średnia wartość temperatury powietrza $\left(-0,9^{\circ} \mathrm{C}\right)$. W kwietniu decydującym czynnikiem jest opad. Większemu plonowaniu sprzyjaja jego mniejsze wartości $(12 \mathrm{~mm})$. Optymalne warunki pogodowe w tym okresie to $12 \mathrm{~mm}$ opadu i średnia temperatura $9,1^{\circ} \mathrm{C}$. Plon rzepaku wzrasta wraz z rosnącą średnią temperaturą powietrza w maju i jest największy, gdy jej wartość wynosi $15^{\circ} \mathrm{C}$, a opady w tym miesiącu są powyżej średniej $(73 \mathrm{~mm})$. Przebieg pogody w czerwcu ma mniejszy wpływ na plony rzepaku niż w trzech okresach poprzednich. Optymalny jest układ: $27 \mathrm{~mm}$ opadu i temperatura $16^{\circ} \mathrm{C}$, które to wartości są najmniejsze $\mathrm{z}$ badanych. $\mathrm{Z}$ uzyskanego modelu wynika ponadto, że na plon rzepaku ozimego dodatni wpływ mają: zawartość w glebie fosforu i potasu oraz nawożenie N, P i K.

Stowa kluczowe: rzepak ozimy, opad, temperatura, Dolny Śląsk

\section{MS. received in December 2013}

\section{Authors' addresses:}

Halina Dzieżyc

Katedra Gospodarki Przestrzennej

Uniwersytet Przyrodniczy we Wrocławiu

50-357 Wrocław

ul. Grunwaldzka 53

e-mail: halina.dziezyc@up.wroc.pl

Kazimierz Chmura, Maciej Piotrowski

Instytut Architektury Krajobrazu

Uniwersytet Przyrodniczy we Wrocławiu

50-363 Wrocław

pl. Grunwaldzki 24a

e-mail: kazimierz.chmura@up.wroc.pl maciej.piotrowski@up.wroc.pl 